Jurnal The Messenger, Vol. 10, No. 1, January 2018, pp. 54-62

P-ISSN: 2086-1559, E-ISSN: 2527-2810

DOI: $10.26623 /$ themessenger.v10i1.550

\title{
Inter-Ethnic Communication Barriers in Pontianak City
}

\section{Hambatan Komunikasi antar Etnis di Kota Pontianak}

\author{
Sinta Paramita ${ }^{1}$, Rose Mita Carissa ${ }^{1}$ \\ ${ }^{1}$ Faculty of Communication Sciences, Universitas Tarumanagara, Jl. Letjen. S. Parman \\ No. 1 Gedung Utama Lt. 11, Jakarta Barat 11470, Indonesia \\ *Corresponding author, e-mail: sintap@ fikom.untar.ac.id
}

\begin{abstract}
This study aims to find out how the expectations of each ethnic group in maintaining the issue of inter-ethnic life harmony in the Province of West Kalimantan, especially in Pontianak City which consists of the majority of the ethnics of Dayak, Malay, and Tionghoa. Multi-ethnic life in Pontianak City often creates various conflicts. This study is a qualitative research using descriptive qualitative method. In this study, the reseachers linked several theories of intercultural communication and identified the communication barriers such as Stereotype, Ethnocentrism, etc. This study found that inter-ethnic conflicts can arise due to the absence of opened mind in facing the differences, the lack of mutual tolerance and mutual respect among ethnic groups. In addition, communication barriers also become one of the factors of the arise of such inter-ethnic conflict.
\end{abstract}

Keywords: Intercultural Communication, Conflict, Communication Barriers.

\begin{abstract}
Abstrak
Penelitian ini bertujuan untuk mengetahui bagaimana harapan setiap kelompok etnis dalam menjaga isu kerukunan kehidupan antaretnis di Provinsi Kalimantan Barat khususnya di Kota Pontianak yang terdiri dari mayoritas etnis Dayak, Melayu, dan Tionghoa. Kehidupan multietnis di Kota Pontianak kerapkali menimbulkan berbagai konflik yang terjadi. Penelitian ini merupakan penelitian kualitatif dengan menggunakan metode kualitatif deskriptif. Dalam penelitian ini penulis mengaitkan beberapa teori komunikasi antarbudaya dan mengidentifikasi hambatan komunikasi seperti Stereotype, Etnosentrisme, dan lainnya. Dalam penelitian ini ditemukan bahwa konflik antaretnis dapat timbul disebabkan oleh tidak adanya pikiran yang terbuka dalam menghadapi perbedaan, tidak adanya sikap saling toleransi dan saling menghargai antar sesama etnis. Selain itu, hambatan komunikasi juga menjadi salah satu faktor timbulnya konflik antaretnis tersebut.
\end{abstract}

Kata Kunci: Komunikasi Antarbudaya, Konflik, Hambatan Komunikasi.

Copyright (C) 2018 Universitas Semarang. All rights reserved.

\section{Introduction}

Indonesia is a country with the most diverse ethnic and cultural backgrounds. Since ancient times, Indonesia has been known as plural society that can not be separated from the slogan "Bhinneka Tunggal Ika". The slogan that the Indonesian glorified means different but still one, it is assumed that from the various differences that exist, Indonesia is a unity. Although Indonesians have diversity of religions, cultures, customs, ethnicities, and languages, Indonesians are required to live together on one land. It can lead to various conflicts based on ethnic differences among certain groups of people who live and settle in a region.

Article History: Received August 05, 2017; Revised January 02, 2018; Accepted January 25, 2018; Published January 31, 2018 
One of the city consisting of multiethnic society is Pontianak city. Pontianak is the capital of one of Indonesia's provinces in West Kalimantan which has population of 5.2 million people in 2015. The population of millions of people consists of different tribes and ethnicities. The majority ethnic groups living in Pontianak are the ethnics of Dayak, Malay, and Tionghoa.

In this study, the researchers hold that the condition of ethnics harmony of Tionghoa, Malay, and Dayak in Pontianak city is interesting to be examined because the three ethnic groups have coexisted on one land. Seeing this plurality, conflicts often arise and can not be avoided from the social life of the people living in Pontianak.

Therefore, the researchers will analyze about how the inter-cultural communication of the same ethnics in Pontianak city and see things that play an important role in causing conflict or in maintaining the issue of harmony among the communication that occurs when the message communicator is a member of a culture and the recipient of the message (communicant) is a member of a different culture. According to Charley H. Dood (in Darmastuti, 2013: 64) intercultural communication involves the communication that involves communication participants representing personal, interpersonal, or group by emphasizing the differences in cultural background that will affect the communication of participants or participants of communication. This means that intercultural communication must occur in all regions that have different groups of cultures or multiethnic communities.

Ahmad Sihabudin in his book entitled "Komunikasi Antar Budaya" said that intercultural communication happens when the message producer is a member of another culture and the recipient of the message is a member of another culture. Thus, the problem to be faced is a situation where a message is encoded in a culture and must be encoded in another culture (Sihabudin, 2013: 21). Samovar, Porter, and McDaniel also said that the communication process will become more complex when the cultural dimension is involved (Samovar, Porter, and McDaniel, 2010: 25). Furthermore, Sanadi sees intercultural communication as communication happened among people of different cultures (can be different of race, ethnic, or socioeconomic, or a combination of these differences (2014: 30).

Based on the above definition, cultural differences inhibit the optimal process and results of communication. In other words, the communication process is not smooth and the communication results are not optimal. What's worse is the occurrence of negative effects, which lead to prejudices, misunderstandings even until the occurence of either symbolic or physical conflicts.

Intercultural Communication Conflict

Conflict according to Wirawan is one of the essence of human life and development which has various characteristics. Every human being has different social status, culture, ethnic, tribe, belief, and life goals. The differences can cause interindividual conflicts (Wirawan, 2009: 1). Intercultural communication that does not run smoothly in the process of delivery, acceptance, and back encoding will lead to misunderstanding among individuals or groups of people. Every individual or group of people will live on the basis of their own cultural patterns. As we know that culture is not only one but very diverse and it makes intercultural communication complex. Another thing that also contributes to the existence of problem among societies with different culture is the communication barrier.

According to Chaney and Martin (in Lubis, 2016: 5) barrier of communication is anything that prejudice. According to Andrik Purwasito (2003: 178) prejudice is one's

Jurnal The Messenger, Vol. 10, No. 1, January 2018, pp. 54-62 
perspective or behavior towards others negatively. Andrik Purwasito also said that prejudice is general statement based on some superficial experiences that are not tested first. Meanwhile, according to Samovar, Porter, and McDaniel (2010: 207) prejudice is a rigid and painful generalization regarding a group of people. The prejudice is painful in the sense that people have an inflexible attitude based on little or no evidence at all.

According to Sinta and Wulan (2016: 165) the harmony among religious believers can be kept because of the existence of democratic culture that has role to apply equality of freedom to all parties in performing religion and gender activities. All efforts to maintain this harmony are the values of life owned by Minahasa community. According to the above experts, researchers can take an example of prejudice in multi-ethnic society. According to Abdulah (2001: 35) it has happened repeatedly in West Kalimantan since 1962 (see Kompas 20/12/2000). Since 1962, the disputes involving Madurese, Malay, Dayak and Tionghoa ethnic groups happened continuously in 1963, 1968, 1972, 1977, 1979, 1983, 1996, 1997, 1999, and 2000. The event happened in Central Kalimantan on February 2001 is an example of how complicated the ethnic issues in Indonesia are. Abdullah further explained that this kind of ethnic conflict is not only happened in Kalimantan, but also in other areas in Indonesia. Conflict between Acehnese and Bataknese or between Malay and non-Malay in North Sumatra; the dispute in Ambon or in Papua, the dispute in North Sulawesi involving Gorontalo or Talaut and in Java itself are full of SARA (tribe, religion and race) issues.

Inter-Ethnic Communication Barrier

Communication barrier is anything that becomes hinder for the existence of effective communication, according to Chaney and Martin (in Simbolon, 2012: 45). Such communication barrier can occur due to ethnocentrism, racist, and stereotype.

1. Ethnocentrism

Porter (in Darmastuti, 2013: 73) gives the definition ethnocentrism is judging other cultures by comparison with one's own. In the views of Porter, ethnocentrism is the judgment of another group of societies by comparing or using their own cultural standards. Nanda and Warms (in Darmastuti, 2013: 73) stated that ethnocentrism is the view that one's culture is superior to other cultures. The view that other cultures are judged based on our culture. Sometimes someone will turn into ethnocentrism, when they see other cultures using their cultural glasses or based on their social position.

While according to Andrik Purwasito (2003: 228) ethnocentrism is cultural egoism. A community considers themselves superior among others and has better selfassessment of culture. Thus, all judgments depart from their own cultural measurement and cause what is best is their own culture, whereas others' cultures are inferior. Based on the explanation of the experts above, it can be seen that this barrier can cause conflict if ethnocentrism is adopted by society in a multiethnic region, because only in multiethnic society a culture can be compared to the others.

2. Stereotype

Andrik Purwasito (2003: 228) defines stereotype as independent based on the cultural environment. Stereotype according to Samovar, Porter, and McDaniel (2010: 203 ) is a complex type of grouping that mentally organizes individual experiences and directs the individual's attitude in confronting certain people. This becomes the way to organize your images into a certain and simple category that you use to represent a group of people.

Based on the experts explanation about stereotype above, the researchers can conclude that stereotype may lead to intercultural conflicts if a group of people from 
culture A depicts a group of culture B incorrectly or negatively and the negative image is based only on the view of an individual who happens to be a group of culture B. It can be said that stereotype sees everyone in a group as having the same nature.

\section{Racism}

Racism according to Leone (in Samovar, Porter, and McDaniel, 2010: 212) is a belief in the superiority inherited by certain races. It is this superiority that enables someone to treat another group badly based on race, skin color, religion, etcetera. Samovar, Porter, and McDaniel also said that racism is the major obstacle in the success of intercultural communication. Without being realized, many types of racism often occur around us. Racism can include acts of humiliation perpetrated against other ethnics, intimidation against other ethnics, even to the point of seriousness reaching the stage of physical violence.

One of the simple examples of racism that happens in our lives, for instance is the formation of group in a class in one of the white-majority schools, there is no single group which wants to include A (the only black student in the class) into their group. It shows that there is a background of racism in the rejection of student $A$ in each group in that class. Sometimes we perform racism consciously or unconsciously, it is caused by the attitude of racism that has been inherited from generation to generation and it can unknowingly attach to our body and mind forever. Based on the introduction above, this study will discuss about the communication of three different cultures. Therefore, the explanation on the communication barrier listed above will be an important study material that can help the researchers to complete this research.

\section{Methodology}

The methodology used in this study is descriptive qualitative. Data collection techniques used include primary data and secondary data. Primary data in this study are the interview to the people in Pontianak City and the observation about communication barrier happened among Dayak, Malay, and Tionghoa ethnics in Pontianak city. The secondary data used in this study are the library research and online observations that are relevant to the research.

After data collection technique is obtained, the following step is data analysis technique. According to Seiddel (in Moleong, 2007: 248) qualitative data analysis has gradual process. The first step is to record the resulting field notes, it is encoded to keep the data source traceable; the second step is to collect, sort through, classify, synthesize, make summary and its index; the last step is to think, by making the data category to have meaning, searching and finding patterns, relationships, and general findings.

In this study, the researchers only follow some technical data analysis presented by the experts above, namely processing the data that have been collected, studying, identifying, and turning it into a meaningful finding. Here are the steps in data analysis techniques conducted by the researchers in this research:

1. Conducting observation by performing interview and direct observation.

2. After collecting the research data by conducting observation, then the next step is narrating the result of interview and observation.

3. After narrating the results of observation, the researchers study and classify the results of these observations.

4. The next step, after understanding the results of the observations the researchers collaborate and analyze the findings with the theories concerned. 
5. The last step is discussion. After analyzing the results of observational data with the theories, finally the researchers can turn it into a meaningful finding.

\section{Result and Discussion}

In a multi-ethnic society, the opportunities for the occurrence of barrier in communication become bigger, this is due to the presence of barrier as revealed in the introduction above. The barrier to communication may be the differemce of culture, linguistic, customs, and others. Here are the communication barriers among the ethnic groups of Dayak, Tionghoa, and Malay in Pontianak city based on the analysis results:

1. The Communication Barrier of Malay ethnic towards ethnics of Dayak, Tionghoa, and Malay themselves

Based on the results of the researchers' interviews with the informants, it is found that there is stereotyping by Malay ethnic to ethnics of Dayak and Tionghoa in Pontianak city. Andrik Purwasito (2003: 228) defines stereotype as common view of a community group against other community groups. This common view is usually negative. Negative view given to a community group is often the trigger of the emergence of conflict. Andrik Purwasito also said that stereotype is built over time, in which each community group has its own interpretation framework based on the cultural environment.

"Kalau menurut aku orang Dayak itu masih mungkin karena memang mereka masih mayoritas gitu ya, jadi masih kolot, rasis, belum bisa bergaul juga dan kurang tenggang rasa dengan etnis lain (I think Dayak people are still possible because they are still the majority, so they are still old-fashioned, racist, unemployed and lack of tolerance with other ethnics)" (interview with Malay ethnic informant on November 19, 2016).

The result of the interview shows that Malay ethnic views Dayak ethnic group is still old-fashioned, racist, and lack of tolerance to other ethnic groups. According to the informant, that is because Dayak ethnic is still one of the majority ethnic groups there. The informant also revealed that the customs of Dayak ethnic community are still very strong and still continue to be performed up to now, it is what makes the informant of Malay feels that Dayak people there are still very old-fashioned. Based on the same sources, the researchers also found that Malay ethnic feels that Tionghoa ethnic in Pontianak are still very closed. According to the informant it is because Tionghoa ethnic population in the province is minority, and also their culture is too different from the culture of Malay and Dayak ethnics, especially in the language used for everyday life. It can be seen from Tionghoa people who mostly still use Tionghoa language (Khek or Tio Chu) in their daily life, whereas Dayak and Malay ethnic groups have mostly communicated with the local language. It also makes the informant feels that there is still racism in Tionghoa ethnic against other ethnic groups there.

"Menurut aku karena Tionghoa masih minoritas, jadi mereka kadang suka menutup diri dari etnis lain. Justru kalau kita mau approach mereka, mereka malah jadinya rasis ke kita karena etnis kita beda, terus cara komunikasi juga beda (I think because Tionghoa is still minority, so they sometimes like to close themselves from other ethnic groups. When we want to approach them, they even become racist to us because our ethnic is different, and the way of communication is also different)" (interview with Malay ethnic informant on November 19, 2016).

Racism according to Leone (in Samovar, Porter, and McDaniel, 2010: 212) is a belief in the superiority inherited by certain races. It is this superiority that enables one 
to treat another group badly based on race, skin color, religion, and others. Malay informant felt that Tionghoa ethnic was still racist against Malay ethnic. It happened when the informant was still in high school, the informant who wanted to approach and introduced himself to one of his friend who was Tionghoa ethnic was responded cynically by the Tionghoa ethnic.

"iya, mereka gak mau bergaul, kayak sinis gitu loh. Terus kayak ngomongin dibelakang gitu (yes, they do not want to hang out, like cynical. It seems they like talking about us behind us)" (interview with Malay ethnic informant on November 19, 2016). This reflects that there is still certain groups of people who treat other communities badly just because of race, ethnic, and other differences in Pontianak.

2. The Communication Barrier of Dayak Ethnic toward Ethnics of Malay, Tionghoa and Dayak themselves

Based on the results of interviews conducted by the researchers with Dayak informants, the researchers found that there is ethnocentrism on Dayak ethnic in Pontianak. Nanda and Warms (in Darmastuti, 2013: 73) stated that ethnocentrism is the view that someone's culture is superior to other cultures. When the researchers conducted interviews, Dayak infromant responded confidencely that the cultures and customs of Dayak ethnic groups were better than those of the Malay and Tionghoa ethnics in Pontianak.

"pastinya lebih baik dong, karena 'kan Dayak itu adat saya sendiri, terus saya dari kecil 'kan hidupnya dengan aturan-aturan orang Dayak (Certainly it's better, because Dayak is my own custom, I have been living with the rules of Dayak since my childhood)."

Informants from Dayak ethnic group also did not give significant reasons why he felt that Dayak culture and customs were better than Malay and Tionghoa. What happens to the Dayak Pontianak ethnic group can also be said as cultural egoism, where the ethnic feels that they are superior and judges their own culture is the best. Ethnocentrism according to Andrik Purwasito (2003: 228) is cultural egoism. A community considers itself superior among others and better self-assessment of culture. Thus, all judgments depart from their own cultural measurement and cause what is best is their own culture whereas others' cultures are inferior. This is proven from the statement of Dayak informants who said that the culture of Tionghoa society that the level of concern among their own ethnic is very low. It is very different from Dayak ethnic who always helps each other and also friendly among Dayak ethnic. Eventhough they do not know each other, people from Dayak ethnic will greet each other if they are the same Dayak ethnic group. In addition to this, Dayak informant who had ever worked with the community of Tionghoa ethnic also gave stereotype to Tionghoa ethnic as having the nature of frugality in financial matters and is a hard worker.

When he was asked about his views of Malay ethnic, the researchers found that there was prejudice of Dayak informant against Malay ethnic. Prejudice according to Andrik Purwasito (2003: 178) is a person's perspective or behavior towards others negatively. Andrik Purwasito also said that prejudice is general statement based on some superficial experiences that are not tested first. According to informant, he was rarely hanging out with people of Malay ethnic. The informant said this was because he felt that people of Malay ethnic tend to be more closed and just want to mingle with their own ethnic.

Jurnal The Messenger, Vol. 10, No. 1, January 2018, pp. 54-62 
3. The Communication Barriers of Tionghoa Ethnic towards Ethnics of Malay, Dayak, and Tionghoa themselves

Based on the interview with one of Tionghoa ethnic community in Pontianak, the researchers also found that there was prejudice of Tionghoa ethnic against Malay ethnic. Prejudice according to Andrik Purwasito (2003: 178) is a person's perspective or behavior towards others negatively. Andrik Purwasito also said that prejudice is general statement based on some superficial experiences that are not tested first.

"orang-orang Melayu itu ya disini mereka suka merasa kalau kelompok mereka 'kan mayoritas, lebih dominan, dan mereka juga menganggap remeh seperti menganggap etnis Tionghoa cuma numpang di Negara ini (Malay people here like feel that their group is majority, more dominant, and they also underestimate Tionghoa ethnic like considering that Tionghoa ethnic just ride in this country)" (interview with Tionghoa ethnic informant on November 16, 2016).

The Tionghoa informant prejudiced that because Malay ethnic is the majority ethnic, they often underestimate Tionghoa ethnic there. In addition, based on the results of interviews and observations, the researchers found that there was stereotype of Tionghoa ethnic against Malay ethnic that Malay ethnic viewed from their life was very wasteful and could not save.

"kalau dari sisi kehidupan, kebanyakan mereka ya gak bisa hemat uang, kebanyakan dari mereka kalau udah dapat uang langsung aja dihabisin (from the side of life, most of them can not save money. When they get money, most of them spend it out at once)" (interview with Tionghoa ethnic informant on November 16, 2016).

Even based on observation result, there is special name used by Tionghoa people to reflect someone who is very wasteful, that is "huannangkuan" which means the nature of the Malay people. So we can imagine how strong the stereotype on Malay people who are considered having such wasteful habit. In addition, the Tionghoa informant also praised the solidarity of Malay ethnic who are considered very high among Malay ethnic. The same thing was expressed by the informant when he was asked about his view on Dayak ethnic. The informants said that Dayak ethnic also have very high sense of solidarity among themselves.

As a Tionghoa ethnic, the Tionghoa informant interviewed by the researchers also criticized the Tionghoa ethnic who were very individualistic there. Individualistic in the sense that among Tionghoa ethnic themselves when one was experiencing difficulties, the others were more ignorant and did not help, unlike Dayak and Malay ethnics whose solidarity among ethnic groups was very high. According to the Tionghoa informant, Tionghoa ethnic there have a mental of workers and business brains. It causes Tionghoa ethnic have rather stingy nature.

4. Maintaining Inter-ethmic Harmony in Pontianak City

In terms of maintaining the harmony of life in an area inhabited by a group of people from various ethnic groups, of course the society must avoid the emergence of conflict. Conflict according to Wirawan is one of the essence of human life and development which have various characteristics. Every human being has different social status, culture, ethnic, tribe, belief, and life goals. The differences can cause conflict among individuals (Wirawan, 2009: 1).

Communication barriers that have been discussed by the researchers above can inevitably lead to inter-ethnic conflict in Pontianak city, therefore there must be the effort or willingness of each ethnic group to be able to live side by side well and harmoniously. To achieve that, of course there must also be attitudes that need to be 
applied by the people of the three ethnic groups. Based on the results of the interviews with the three informants, the researchers find out that there is awareness of these three ethnic groups in maintaining inter-ethnic harmony in Pontianak city.

"Biar rukun dan mengurangi konflik mungkin kita cukup saling menghargai sih, toleransi antarsesama. Nah mungkin bisa kita buat acara perkumpulan antaretnis mungkin, agar dapat menjalin hubungan yang lebih baik antar sesana, dan untuk etnis apapun, janganlah mudah terprovokasi dan berpikirlah lebih terbuka (to get along and to reduce conflict we may should respect each other, tolerant among the people. Well maybe we can have an inter-ethnic gathering, in order to establish a better relationship among the people. And for any ethnics, do not be easily provoked and think more open minded)" (interview with Tionghoa ethnic informant on November 16, 2016).

"Pertama sih pasti toleransi sesama etnis, terus kita 'kan juga tinggal di Indonesia yang Bhineka Tunggal Ika jadi gak boleh egois, gak boleh terlalu mikir kalau etnis kita itu paling baik. Dan juga jika sedang berada ditempat umum sebaiknya kita berkomunikasi menggunakan bahasa Indonesia yang baik dan benar biar gak ada kesalapahaman, dan juga saling menghargai antar sesama etnis lain (First of all must be tolerant among ethnic fellows, we also live in Indonesia with its Bhinneka Tunggal Ika, so do not be selfish, do not think that our ethnic is the best. And we also are in public place, we should communicate using good and correct Indonesian language to avoid misunderstanding, and also respect other ethnics)" (interview with Malay ethnic informant on November 19, 2016).

"Mungkin harus saling menghargai dan menjaga, menghargai misalnya kalau kita tau 'kan orang Melayu tidak makan daging jadi usahakan kita gak makan dan menyuguhkan makanan itu kepada mereka (Maybe we should respect and care each other. Respect for example if we know that Malay people do not eat meat, so try not to eat and serve meat to them)" (interview with Dayak ethnic informant on November 21, 2016).

Based on the interviews from three different ethnic groups living side by side in Pontianak city that researchers describe above, it can be seen that every ethnic group is aware of the need for mutual respect and tolerance among other ethnic groups, as well as reducing the existing of cultural egoism. As expressed by one of the cultural figures named Octavianus Shellin Panaloan who is the Chairman of Dayak Kapuas Hulu Youth Association that all people should be aware if we are all just ordinary people who happen to have different ethnic, so there is not matter that needs to be questioned.

"saya mengharapkan setiap orang menyadari bahwa kita adalah sesama manusia, etnis yang kita miliki hanyalah sebuah kebetulan, jadi untuk apa mempermasalahkan itu. Berkali-kali kita dihantam sejarah yang memperlihatkan bagaimana kejamnya diskriminasi antaretnis maupun ras, baik di dalam maupun luar negeri. Semoga semua orang berbahagia menjadi manusia, bukan menjadi etnis A atau etnis B (what I expect is that everyone realizes that we are human beings. The ethnicity we have is just a coincidence, so why shoult it bother us? Many times we are hit by history that shows how cruel the racial and inter-ethnic discrimination, either at our own country or abroad. May everyone be happy to be human beings, not to be ethnic A or ethnic B)" (interview with the Chairman of Kapuas Hulu Dayak Youth Association, Octavianus Shellin Panaloan).

Jurnal The Messenger, Vol. 10, No. 1, January 2018, pp. 54-62 


\section{Conclusion}

Communication barriers that can cause inter-ethnic conflict in Pontianak City can occur because of ethnocentrism, racism, and stereotype in the society. In addition, cultural egoism also still attached to the some people in certain ethnic groups. Like the Dayak ethnic group which is one of the majority ethnic in Pontianak City who consider themselves superior among Tionghoa and Malay ethnics. Dayak and Malay ethnic groups are the ethnics who have high level of solidarity among their ethnic groups. Malay ethnic group is the ethnic group who is most frequently generate conflict.

Such communication barriers can create inter-ethnic misunderstandings in Pontianak and eventually lead to inter-ethnic conflict. To achieve harmony in the life survival of Malay, Dayak and Tionghoa ethnic communities in Pontianak, it is expected that there is sense of tolerant, mutual respect and not easily provoked by irresponsible people.

\section{Acknowledgement}

Gratitudes are given to Faculty of Communication Science of Universitas Tarumanagara, then to the informants who have provided relevant information related to this research, and to the people in Pontianak City.

\section{References}

Abdulah, I. (2001). Penggunaan dan Penyalahgunaan Kebudayaan di Indonesia: Kebijakan Negara dalam Pemecahan Konflik Etnis. Jurnal Antropologi Indonesia, 66, 34-45.

Darmastuti, R. (2013). Komunikasi Antarbudaya: Konsep, Teori dan Aplikasi. Yogyakarta: Buku Litera Yogyakarta.

Lubis, A.L. (2016). Pemahaman Praktis Komunikasi Antarbudaya. Medan: USU Press.

Moleong, L.J. (2007). Metodologi Penelitian Kualitatif. Bandung: PT. Remaja Rosdakarya.

Paramita, S., Wulan, P.S. (2016). Komunikasi Lintas Budaya dalam Menjaga Kerukunan Antara Umat Beragama di Kampung Jaton Minahasa. Jurnal Pekommas, 1 (2), 153-166.

Purwasito, A. (2003). Komunikasi Multikultur. Yogyakarta: Pustaka Pelajar.

Samovar, A.L., Porter, E.R., McDaniel, R.E. (2010). Komunikasi Lintas Budaya. Jakarta: Salemba Humanika.

Simbolon, D. (2012). Memahami Komunikasi Beda Budaya antara Suku Batak Toba dengan Suku Jawa di Kota Semarang (Studi pada Mahasiswa Suku Batak Toba dengan Suku Jawa di Universitas Semarang). Jurnal The Messenger, 4 (2), 43-49.

Sihabudin, A. (2011). Komunikasi Antar Budaya: Satu Perspektif Multidimensi. Jakarta: PT. Bumi Askara.

Wirawan. (2009). Konflik dan Manajemen Konflik: Teori, Aplikasi, dan Penelitian. Jakarta: Salemba Humanika. 